\title{
Conditions and challenges for Polish-Chinese trade cooperation in high-tech goods
}

\author{
Celestyna Miłoś
}

\begin{abstract}
A B S T R A C T
Objective: The objective of this article is to discuss the contemporary conditions for Polish-Chinese cooperation in the area of trade in high-tech goods and to identify barriers to the development of cooperation between the two countries in order to achieve tangible economic benefits.

Research Design \& Methods: This study is based on two research methods, which made it possible to obtain and analyse qualitative and quantitative data. The methods used included desk research of existing data and research in the form of individual in-depth interviews (IDIs). The desk research was carried out on the basis of data on the conditions for trade exchange, while the IDI survey was conducted on the basis of scenarios developed for this purpose, which were the basis for interviews with representatives of government.

Findings: The article presents research results on trade in high-tech goods with conclusions on the way forward. The result of the conducted research is the identification of the potential for the development of economic and political cooperation between Poland and China, which lies in the possibility of increasing trade in high-tech goods. This can be realised by increasing the involvement of Polish enterprises, especially start-ups, in export activities.

Implications \& Recommendations: Poland and China have great potential for closer economic cooperation, which can bring economic benefits to each country.

Contribution \& Value Added: The article compares quantitative data with qualitative data, which were obtained through in-depth interviews conducted with representatives of government administration.

Article type: research article

Keywords: $\quad$ Poland; China; trade; international cooperation; high-tech

JEL codes: $\quad$ F02

Received: 4 June $2021 \quad$ Revised: 13 August $2021 \quad$ Accepted: 24 August 2021
\end{abstract}

\section{Suggested citation:}

Miłoś, C. (2021). Conditions and challenges for Polish-Chinese trade cooperation in high-tech goods. International Entrepreneurship Review, 7(3), 47-60. https://doi.org/10.15678/IER.2021.0703.04

\section{INTRODUCTION}

China is now the world's largest economy, both in terms of GDP at $\$ 14,722$ billion and population at 1.4 billion (World Bank, 2021a). As recently as the 20th century, China was considered a producer of low-quality, low-cost goods, but today it is striving to become a leader in highly advanced technologies. These changes are occurring very rapidly in the Chinese economy and are characterised by the government's structured and consistently implemented actions, as exemplified by the assumptions of the current 14th Five-Year Plan and the strategic programmes "Made in China 2025" and "China Standards 2035". As society's demand for medium- and high-tech goods is growing, a leading position in the field of manufacturing these goods is important for the Chinese economy's presence among global leaders. Poland is a country that, like China, has undergone important economic and political transformations in recent decades. Despite its smaller market of 37.97 million in terms of population (World Bank, 2021b), it is an important part of the European market due to its location.

Taking into account the rapid economic development of China in terms of medium- and high-technology goods industries and the expansion of the international cooperation network in terms of trade 
exchange, this article examines the prospects for Polish-Chinese cooperation and the barriers in trade. These aspects depend on historical factors relating to the countries' cooperation and technical aspects of trade such as tariff and non-tariff barriers. The topic has not been thoroughly researched from this angle so far, which is due to little political involvement in the Polish-Chinese relations, which are largely shaped by the European Union's external policy. Because of the need to build the EU's relations with two conflicting economic powers, which include the United States and China, these relations are not obvious. In practice, the EU trades extensively with China, but in terms of political relations the EU is more conservative. In view of the initially identified positive aspects of Polish-Chinese cooperation, this article aims to explore the directions of cooperation based on barriers. To this end, the research questions have been developed, which directly derive from the aim of the research article:

RQ1: To what extent is Polish-Chinese trade cooperation in the production of high-tech goods developed?

RQ2: What are the biggest barriers hindering the development of Polish-Chinese trade cooperation?

RQ3: Which industries are the most promising for Polish-Chinese trade cooperation development?

The study was based on statistical data on trade exchange. The study was also based on an individual in-depth interviews (IDIs) conducted with representatives of the public administration responsible for the development of Polish-Chinese relations.

The article is organised according to a structure containing in turn a review of the literature on the formation of Polish-Chinese economic relations, followed by a detailed presentation of the research methodology and conclusions.

\section{LITERATURE REVIEW}

\section{Evolution of trade theory}

The concept of trade in theoretical terms is under constant development. This is due to the evolution of the world economy, which is constantly evolving in terms of organisation and technology, affecting changes in the way trade is conducted. This aspect is also dependent on the coexistence of different trade theories, theorems and paradoxes described so far, which are confronted and developed with each other. This allows the development of contemporary theories that are a better representation of trade theory than the classical theories. The direction of change in contemporary theories can be described as an effort to create a model that is as up-to-date as possible and that broadly encompasses the complexity of factors affecting international trade. It is worth noting that these factors also include new phenomena in the economy, such as increasing globalisation leading to the removal of trade barriers and lowering transport costs, global crises, or increased mobility of capital, goods and people (Kundera, 2018, pp. 18-20).

At present, theories, theorems and paradoxes are grouped in the literature according to the division into pre-classical, classical, neoclassical and modern theories, of which the first three are combined as traditional theories (Świerkocki, 2004a, p. 18) or standard theories and new theories of international trade (Wach, 2018, p. 64). The genesis of the process of developing theories on trade exchange took place during the Renaissance. Initially, they were primitive in nature and based on basic observations of economies. The psychosis of fear of shortage of goods is considered to be the first theory (Olesiuk \& Vashchenko, 2001, p. 141). Important in the process of development of economical thought in the field of international trade were the assumptions of mercantilism and physiocratism, which made it possible to capture the factors and directions of foreign trade. The classical theories, which include the absolute cost advantage theory of Smith, the theory of comparative advantage of Ricardo, Torrens and Mill, the real cost theory of Viner and the opportunity cost theory of Haberler, have had the greatest influence on the evolution of international trade theory. However, they are distinguished by major limitations imposed by the assumptions made. These include the use of only two countries in the models, the limitation of the number of products to two, the assumption 
of a complete absence of trade barriers, a balanced trade balance and factor restrictions. These assumptions result in models that to a small extent reflect conditions actually prevailing in the world economy. Neoclassical theories were enriched by the addition of further variables, which at the same time resulted in a more accurate representation of the real situation in economies by including in the model the difference between the cost of labour and the cost of capital required to produce a given good. The first neoclassical theory was the resource abundance theory, which accounted for the expansion of foreign trade motivated by the use of a more abundant factor of production. The later equilibrium theory of factor prices allows us to understand the process of equalization of prices in countries trading with each other. It occurs through a process of decrease in the price of a good in the country where the product was more expensive and a simultaneous increase in the price of the good in the country where the product was cheaper. This simultaneously leads to a change and equalisation of factor prices (Świerkocki, 2004b, p. 23). Contemporary trade theories include the technology gap theory of Posner, which makes trade dependent on the different technological level of countries (Posner, 1961, p. 332), the product life cycle theory of Vernon, which states that there are different stages of market presence of a product in terms of popularity and price, the theory of economies of scale of Krugman, which states that unit costs are decreasing with increasing production, and the theory of intra-industry trade of Balassa showing trade within the same groups of goods. In the group of contemporary theories there is also Linder's hypothesis stating that exports are conditioned by production defined by domestic demand (Borkakoti, 1998, p. 366).

In the context of trade in technological goods, contemporary theories play an important role: Linder and Helpman. Linder's theory plays a very important role in the contact of technology-related products. This is because Linder stated that countries with similar demand will create similar industries. Helpman, on the other hand, showed that a larger share of trade between countries results in smaller differences in society's income (Panda, Sethi \& Chaudhuri, 2016, pp. 2-3).

\section{Institutional conditions of international cooperation}

After the end of the Second World War, it was necessary to develop a new legal framework shaping international cooperation. To this end, states started talks on establishing a new order, including in the aspect of international trade. During the talks between representatives of the states, including at the Bretton Woods Conference, attention was drawn to the need to create an international institution responsible for developing trade. After two years of negotiations, 23 countries concluded the General Agreement on Tariffs and Trade (GATT) on 30 October 1947. Initially, the agreement adopted was intended to be temporary, and the International Trade Organisation was to be set up as a result. Work on its creation lasted from 1945, when the USA initiated the first talks with the allies, until 1948, when the so-called Havana Charter was drafted, establishing a new organisation in the field of trade and the International Clearing Union, but due to repeated rejection of the treaty by the American Congress, the idea of opening an organisation was abandoned (Bossche, 2005, pp. 80-81). The failure to establish an international organisation meant that the only aspect that cemented international trade was the GATT. Therefore, it was decided to transform the agreement from a temporary solution to a permanent one. The change in the nature of the GATT resulted in the need to reorganise the operation of the agreement. Hence, the so-called Rounds were introduced, during which further improvements in international trade regulations were agreed. These rounds had a specific trade theme, which was negotiated by the members of the agreement within the framework of the round. The main focus was on the liberalisation of trade through tariff reductions and the elimination of trade barriers. As part of the Uruguay Round, the World Trade Organisation (WTO) was established in 1995, replacing the GATT. During the eight rounds conducted so far, the average level of tariffs, taking into account the changes introduced by each negotiating round, was reduced from $40 \%$ in 1947 to $6.6 \%$ in 1994. (WTO 2007, pp. 207-220). The WTO has established rules in international trade that govern aspects of trade, including trade in high-tech goods. These include The Information Technology Agreement (ITA), which abolished tariffs on selected IT and ICT goods allowing greater accessibility to high-tech goods (Portugal-Perez, Reyes \& Wilson, 2006, p.4). As part of its efforts to standardise trade in high-tech goods, the WTO has also adopted the Agreement on 
Trade-Related Aspects of Intellectual Property Rights (TRIPS), which makes the protection of intellectual property rights among its members as uniform as possible (Rasiah, 2002, p.9).

In addition to the WTO, which has had the most significant and global impact on international trade, many other organisations and regional integration groupings dealing with trade-related economic cooperation have been established since World War II. The most important institutions established after World War II include: (i) Council for Mutual Economic Assistance (COMECOM), whose main objective was to support the economic and scientific-technological development of the Eastern Bloc countries; (ii) Organisation for Economic Cooperation and Development (OECD), whose main objective is to promote economic development, liberalise capital flows and support the economic expansion of countries; and (iii) the Commonwealth of Independent States (CIS), which aims to maintain cooperation between the former Soviet Union countries; (iiii) European Coal and Steel Community/European Economic Community, which economically united the countries of Europe (Łoś-Nowak, 2009, pp.380-384). The formation of integration groupings, the number of which started to increase significantly in the 1990s, causes disputes among members of international organisations, regional trade agreements (RTAs) and experts. The impact of regional cooperation on the process of globalization and enhancing cooperation among all countries is a debatable issue, as privileged treatment of countries within a regional arrangement simultaneously results in discrimination against third countries. However, the WTO has recognised that the impact of regional cooperation is not unequivocally negative towards the multilateral system and the liberalisation of world trade and, especially in the initial phase, has been supportive of the globalisation process. This is due to the actions taken by the RTA, related to the general reduction of tariffs and multilateral market opening reducing discrimination (WTO 2007, pp. 207-220). The major RTAs established after World War II include Association of Southeast Asian Nations (ASEAN), European Free Trade Association (EFTA), Asia-Pacific Economic Cooperation Forum (APEC), Southern Common Market (Mercosur), Central European Free Trade Association (CEFTA), European Union (EU), United StatesMexico-Canada Agreement (USMCA), African Union (Białowas, 2006, p. 60).

\section{Economic and political conditions of Polish-Chinese cooperation}

Polish-Chinese cooperation in the political, economic and scientific spheres has been ongoing since the mid-20th century. The beginning of contemporary relations dates back to the 1990s, which is associated with the building of international cooperation after the political changes in Poland and the growing importance of China on the international arena.

"China became the most significant partner in intra- and inter-regional domestic value added trade in intermediate products. Its role has grown not only in Asia, but it can be said that it is becoming a world supply hub." (Nacewska-Twardowska, 2020, p.75)

Since 1990 representatives of the Polish government have taken steps to build and intensify cooperation between the countries. Initially, these were diplomatic activities consisting of visits by representatives, which resulted in the conclusion of intergovernmental agreements on cooperation with parallel maintenance of cooperation at the level of ministries or independent organisations dealing with culture and scientific development (Stec, 2013, pp. 76-78). The most important acts consolidating cooperation at the state level include an agreement on financial cooperation concluded in 2000 and a bilateral agreement on economic cooperation concluded in 2004, which indicated closer cooperation in sectors such as industry and mining, science and technology, energy, communications and transport. Cooperation in the field of product certification and standardisation or the development of consulting, legal and banking services have been identified as tools leading to the development of cooperation (Hołdak \& Konarzewska, 2007, pp. 282, 285). During the second decade of the 21st century, cooperation intensified, as evidenced by the establishment of the Polish-Chinese Strategic Partnership in 2011 and the subsequent upgrading of relations to the level of the All-Party Strategic Partnership in 2016. This allowed the establishment of cooperation including regular intergovernmental committee meetings and the organisation of visits by top-level representatives (Szczudlik-Tatar, 2015, p.1).

Institutions, both governmental and non-governmental, are primarily influential in shaping the relationship. The most important government administration entities include the Embassy of Poland in 
China, the Consulate General of Poland in Hong Kong, the Consulate General of Poland in Guangzhou, the Consulate General of Poland in Shanghai, the Embassy of the People's Republic of China in Poland, the Consulate General of the People's Republic of China in Gdansk. Non-governmental institutions include chambers of commerce, chambers of commerce and industry, and business councils, which bring together representatives of enterprises and are active both in building political relations and creating a friendly business environment.

The ongoing talks on cooperation between the countries are related to China's strategic plans for economic development. One of the leading initiatives is the Belt and Road Initiative (BRI) (formerly the One Belt One Road, OBOR), which involves the expansion and creation of new road, rail and sea links across Eurasia. Together, these will provide transport links to 71 countries, which are home to $60 \%$ of the world's population. The idea is that this will allow further development and acceleration of freight transport, strengthening the competitiveness of Chinese goods. Cooperation on the project largely concerns Poland, which is to be one of the destination points for the new rail link running through Kazakhstan, Russia, Belarus, Poland and Germany, with the main rail hub to be the one in Łódź (Brona, 2018, pp. 58-59).

The most significant in terms of trade in high-tech goods is the Made in China 2025 programme, established in 2015. In addition to identifying general strategic tasks, such as improving manufacturing innovation, expanding the industrial base, restructuring the manufacturing sector or internationalising production, the Plan also sets specific objectives. These are plans to achieve the following economic results in 2025 (Gacek, 2018, p.11):

- increase the proportion of Chinese components in final products by 30 p.p., to $70 \%$,

- to increase production of telecommunications equipment by 5 p.p. to $80 \%$ domestic market share and by $5 \mathrm{pp}$ to $40 \%$ global market share,

- to increase production of mobile devices by 5 p.p., to $80 \%$ domestic market share and by 20 p.p., to $45 \%$ global market share,

- to increase production of integrated circuits by 5 p.p. to $40 \%$ domestic market share and by 5 p.p. to $20 \%$ global market share,

- to increase production related to the Internet of Things - IoT by 20 p.p., to $60 \%$ of the global market share,

- to increase production related to robotics by 20 p.p., to a $70 \%$ share of the global market,

- increase production related to electric vehicles by 15 p.p. to $20 \%$ of global market share.

Of the goals mentioned above, the most important is the aspect of semiconductor manufacturing, used in the production of electronics. This priority is supported by advances in the technology of chips necessary for information processing, which in turn become the basis of all modern intelligent systems (VerWey, 2019, p. 13).

The latest developments on the Poland-China line also concern the Comprehensive Agreement on Investment between the European Union and China, which is intended to redress the growing asymmetry in foreign investment, consisting of broad access to the EU market while discriminating against European countries in the Chinese market (Amal, 2021, p. 2). This agreement was concluded in 2020, but due to incidents regarding the imposition of mutual sanctions on diplomatic representatives, it was frozen. This resulted in a deterioration of relations and a temporary halt to talks between representatives of the countries.

\section{Challenges for economic cooperation between Poland and China}

Looking at the geopolitical determinants of economic cooperation, it is important to note the growing importance of Poland in the international arena and especially in the European Union, which, despite its location in the center of the continent and its title as a leader in the Eastern European region, was not obvious (Wnedt, 1997, p. 61). Poland being a country located in central Europe is of great economic importance due to its strategic location in terms of transport. At the same time, the country is the external border of the European Union, bordering Ukraine and Belarus, which are not members of the community and are also former Eastern Bloc countries. Poland's foreign policy is characterised by 
strong relations built with the United States, mainly through cooperation within NATO. In addition, despite a number of blockages, Poland is also strengthening cooperation with members of the European Union, with the greatest importance being placed on strengthening cooperation with Central and Eastern European countries, particularly within the Visegrad Group (Lach, 2014, pp.17-19). Strong cooperation with the countries of Central and Eastern Europe is also a way to strengthen cooperation with China through the ' $16+1$ ' initiative.

"One of such innovative approaches to regional cooperation, established in 2012, is the ' $16+1$ '; the initiative that serves China's vision to increase its political influence in the world and on CEECs by promoting China-European Union (EU) relations. The ' $16+1$ ' initiative is regarded by Chinese as 'one of the most important achievements of China'” (Jaklič \& Svetličič, 2019, p. 84)

Determinants of cooperation with China are large extent conflict of interest regarding the alliance with the United States, as a result of the dispute between the two countries initiated by the suspicion of espionage by Huawei. The tense relations between the two superpowers mean that Poland's foreign cooperation has to take a course in the development of diplomatic relations, the effects of which may affect long-term cooperation for years to come. On the one hand, the country has normalised relations with the US and its allies, while on the other, it has the opportunity to build relations with the rapidly developing Middle Kingdom, which is becoming known as a global leader in technology and innovation.

Based on the literature review, a hypothesis was formulated as follows:

H1: There is a potential in Polish-Chinese cooperation in trade in high-tech goods, which is insufficiently exploited due to existing barriers.

In order to confirm or reject the hypothesis, the research procedure was adopted and the following research questions were constructed (RQ1, RQ2, RQ3 in the introduction). These questions will serve to determine the directions for the development of the countries' economic cooperation.

\section{RESEARCH METHODOLOGY}

\section{Research approach}

Both quantitative and quantitative methods were used to carry out the analysis in order to provide reliable answers to the research questions. Both methods were used due to easier comparison of quantitative data, which are presented in a numerical form. It also allows trends to be identified and values to be forecast. The disadvantage of quantitative data is that it is not possible to capture all aspects. For this reason, the study also included qualitative data to allow an in-depth study of the situation. The choice of the two research methods required the research to be carried out on the basis of a plan covering successively:

- for quantitative data:

o review of available data sources,

o structuring of data,

o development of databases for research purposes,

$\circ$ development of graphs and tables,

o data analysis,

- for qualitative data:

o development of research tools,

o conducting data collection procedure,

$\circ$ arranging the data obtained,

$\circ$ data analysis.

Following the above procedures of the applied research approach, a comprehensive analysis of the quantitative and qualitative data was carried out, which allowed the study results to be compiled and conclusions to be drawn. 


\section{Data}

The study used reliable quantitative data from databases containing information on trade and the economic situation of individual countries, so the mix of methodologies was applied.

In the part based on quantitative data, the following statistics were selected for the study: data on the value of exports between the countries, the percentage value of Polish exports to China and Chinese exports to Poland, the value of Polish exports to China and Chinese exports to Poland in 2010 and 2020 by product groups classified as high-tech goods, the value of trade deficit and trade surplus in the exchange of goods between Poland and China, the average percentage value of tariffs of China and Poland. The above-mentioned data were obtained from the databases of the World Trade Organisation, the World Bank, the United Nations, the Analysis and Decision Support System of Statistics Poland (GUS) and The Observatory of Economic Complexity. To maintain comparability of data, they have been reduced to the same units of measurement, and the period of data analysis has been taken as data from 2010.

The research part using qualitative data was obtained directly for the analysis by interviewing government officials responsible for shaping Polish-Chinese economic relations.

\section{Research methods}

The study used desk-research methods and descriptive statistics to analyse the data to develop conclusions. For this purpose, tools in the form of platforms constituting interactive databases and excel sheets with data developed for the study were used.

The second research method used is individual in-depth interview (IDI). The interviews for this study were conducted by the author of the study, having the necessary knowledge of the subject matter of the interview, the expertise of the respondents and the ethical principles of interviewing. The interviews were conducted between April and May 2021, in the form of video conversations lasting approximately 60 minutes conducted with the help of distance communication tools. In accordance with the standard for IDIs, the interviews were conducted on the basis of a scenario developed using a list of information sought in the context of the research topic. The script developed as a research tool is presented in Table 1.

Table 1. Script for an individual in-depth interview with government officials involved in cooperation with China

\begin{tabular}{|c|l|}
\hline Thematic scope & \multicolumn{1}{c|}{ Specific questions } \\
\hline Respondent's & Which government authority is represented by the Respondent? \\
\cline { 2 - 3 } Characteristics & To what extent is the organisation involved in Polish-Chinese political and commercial relations? \\
\hline & How has China's policy towards Polish-Chinese trade changed over the past years from Po- \\
land's point of view, and are these changes rather positive or negative? \\
- If positive, then: \\
$\circ \quad$ why? \\
China-Poland re-
\end{tabular}

Source: own compilation. 
The selection of experts taking part in the interviews was made so as to enable verification of the quantitative research carried out and to make objective and reliable forecasts for the future. Interviews were conducted with representatives of government administration dealing with co-operation between Poland and China. The respondents were:

- Aleksander Dańda - the Consul General of the Republic of Poland in Hong Kong.

- Karol Pęczak - the Vice Consul / Head of the Economic Affairs, Communication and Public Diplomacy Department of the Consulate General of the Republic of Poland in Guangzhou.

The purpose of interviewing separate groups was to find out two different perspectives on conditions such as trade barriers to mutual cooperation, support programmes or the involvement of entities in foreign activities.

\section{RESULTS AND DISCUSSION}

\section{Desk-research}

The contemporary world economy is largely defined by the increasing number of links between countries. Above all, this phenomenon relates to the liberalisation of the movement of people, capital and goods, which can be examined through data on the volume and direction of trade.

Considering the trade exchange between Poland and China, the intensity and structure of trade exchange between the countries should be taken into account. The change in nominal value of Polish export to China and Chinese export to Poland is presented in Figure 1. Data presented in Figure 1 shows the growth dynamics of trade exchange between Poland and China. In value terms the nominal growth of China's export to Poland is in indicated period much higher than the growth of export of goods from Poland. In percentage terms, the value growth amounts to $154 \%$ in case of Polish export to China and $222 \%$ in case of Chinese export to Poland.

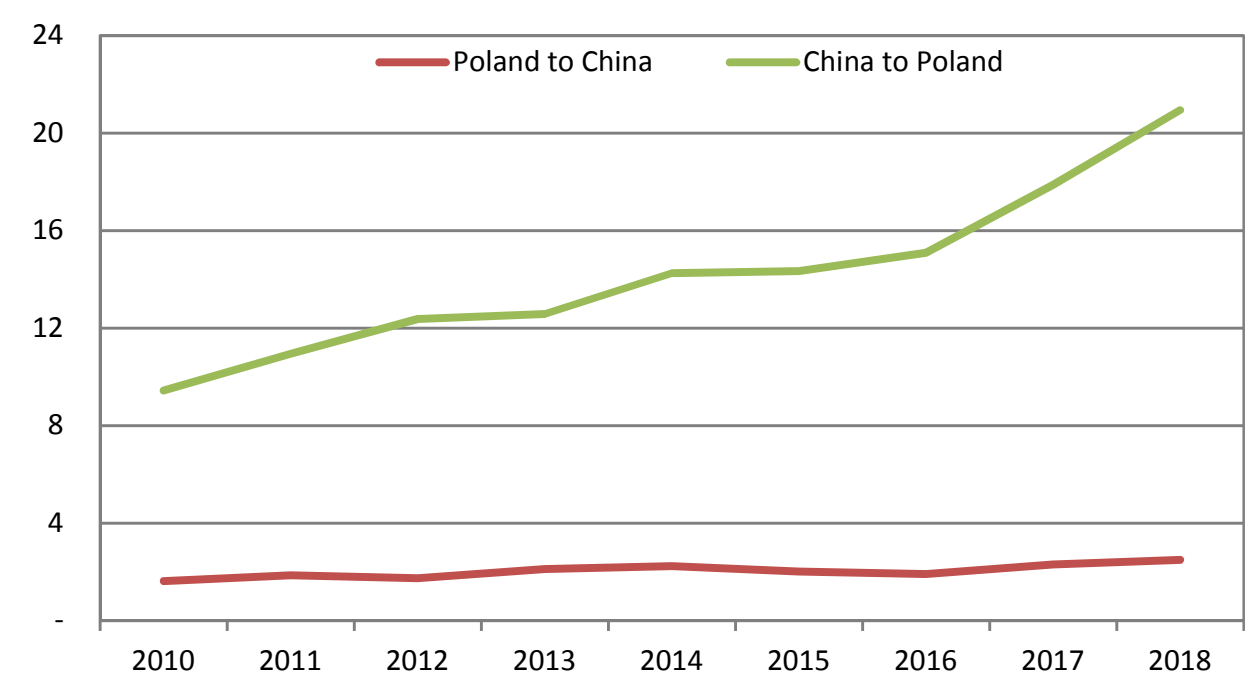

Figure 1. Nominal value of Polish exports to China and Chinese exports to Poland of goods and services in 2010-2018 (billions of USD)

Source: own elaboration based on World Integrated Trade Solution (2021).

Nominal value of trade exchange between Poland and China shows high imbalance, which is reflected in the trade balance. Its value is negative for Poland and positive for China, which is equivalent to a surplus of imports from China over exports. The data presented in Figure 2 shows Poland's growing trade deficit with China, which amounted to USD 18.442 billion in 2018 and shows a further upward trend. This relation proves the outflow of capital from Poland and negatively influences the country's balance of payments. 


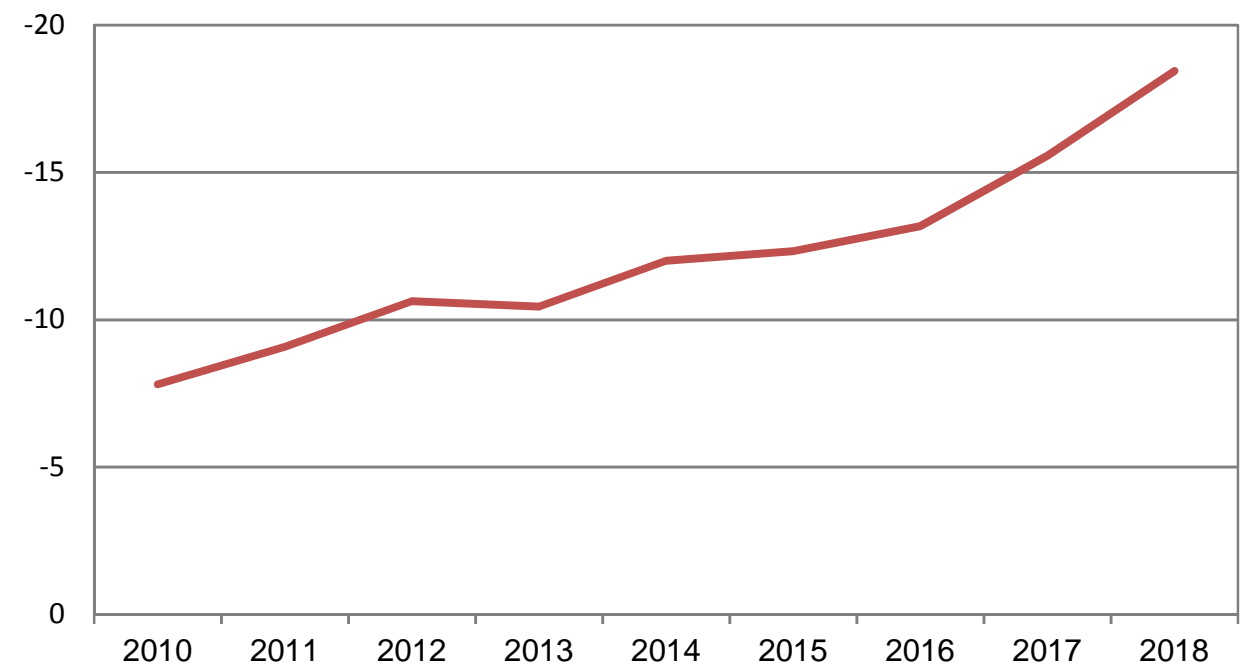

Figure 2. Poland's trade deficit with China in goods and services in 2010-2018 (billions of USD) Source: own elaboration based on GUS (2021).

While examining the mutual trade of the analyzed economies, the percentage share of a country in the export structure should also be taken into account. For this purpose, Figure 3 presents data on the percentage value of export from Poland to China and from China to Poland. This value refers to the total value of export of a given country and allows to illustrate the importance of mutual trade. The data presented in Figure 3 at the end of the period amount to 1.1\% share in the exports of both Poland and China. The analysis of aggregated data shows a systematic increase of Poland's share in China's export structure and in case of China's share in Poland's export the values remain at an almost similar level. This means that mutual trade is for China, however it should be noted that for both countries the share of trading partner is relatively small. For example, in the case of China's export structure, the United States is in first place, to which $19.30 \%$ of goods were exported in 2019 , and Poland with a value of $1.1 \%$ is in 25 th place. In the case of Poland's export structure, which is much less diversified, the main partner is Germany to which $28.15 \%$ of goods were exported and China with a value of $1.1 \%$ is in 29 th position.

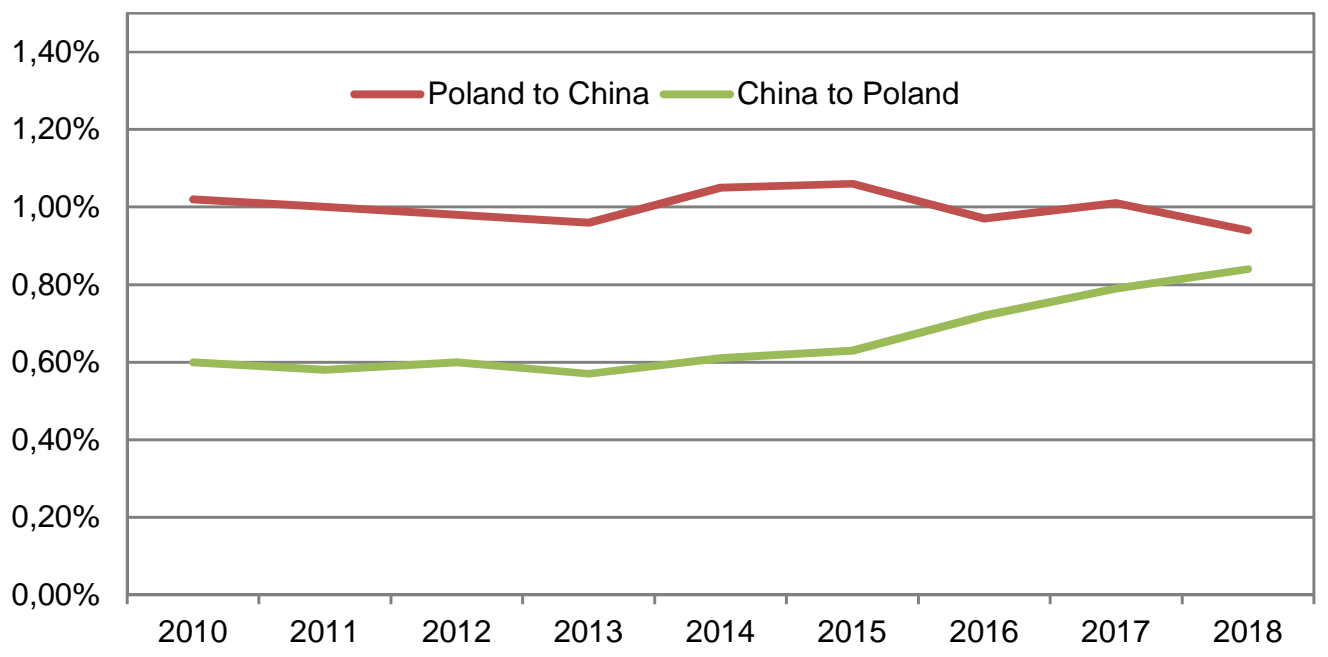

Figure 3. Percentage share of Polish export to China and Chinese export Poland in goods and services to in 2010-2018

Source: own elaboration based on World Integrated Trade Solution (2021). 
Changes in trade values concerning high-tech goods were analysed on the basis of several product groups categorised according to the Harmonised System commodity classification developed by the World Customs Organization. The comparison of values is presented in Table 2. The Table shows that in case of export of goods from China as many as six product groups have recorded an increase in trade exchange. The highest growth in percentage terms concerns group no. 88 , while in value terms - group no. 85 . Value of export of goods from Poland to China is much smaller in value terms, and positive change of value was recorded in five product groups. The highest increase in percentage terms concerns group no. 89, and in value terms - group no. 84. Also, in case of trade exchange of high-tech goods distinguished in Table 2, we can observe that percentage change of total export value shows higher increase in case of Polish export to China in the analysed years. Comparing the value of export of other European countries to the value of export of Poland it should be noted that countries such as France, Germany or Great Britain in 2020 exported to China in each of the mentioned product groups goods worth much more than Poland. It should also be noted that the share of the above-mentioned product groups in the total value of trade recorded an increase during the studied period. It amounted on average to $22.8 \%$ in case of export of goods from China to Poland and $7.7 \%$ of Poland to China.

Table 2. Value of Polish export to China and Chinese export to Poland in 2010 and 2020 by product groups belonging to high-tech goods (in millions of USD)

\begin{tabular}{|c|c|c|c|c|c|c|}
\hline \multirow{2}{*}{ Product group by HS code } & \multicolumn{3}{|c|}{ China to Poland } & \multicolumn{3}{|c|}{ Poland to China } \\
\hline & 2010 & 2020 & change & 2010 & 2020 & change \\
\hline $\begin{array}{l}84 \text { - nuclear reactors, boilers, machinery and mechan- } \\
\text { ical appliances; parts thereof }\end{array}$ & 2374.4 & 4606.9 & $94 \%$ & 211.6 & 753.6 & $256 \%$ \\
\hline $\begin{array}{l}85 \text { - electrical machinery and equipment and parts } \\
\text { thereof; sound recorders and reproducers, television } \\
\text { image and sound recorders and reproducers, and } \\
\text { parts and accessories of such articles }\end{array}$ & 2449.4 & 7505.2 & $206 \%$ & 140.2 & 365.5 & $161 \%$ \\
\hline $\begin{array}{l}86 \text { - railway or tramway locomotives, rolling stock and } \\
\text { parts thereof; railway or tramway track fixtures and } \\
\text { fittings and parts thereof; communication-signalling } \\
\text { equipment of all kinds }\end{array}$ & 4.2 & 29.4 & $606 \%$ & 2.7 & 8.7 & $227 \%$ \\
\hline 87 - non-rail vehicles and their parts and accessories & 392.2 & 866.9 & $121 \%$ & 59.9 & 116.6 & $95 \%$ \\
\hline 88 - aircraft, spacecraft and parts thereof & 0.21 & 31.9 & $15133 \%$ & 50.4 & 1.9 & $-96 \%$ \\
\hline 89 - ships, boats and floating structures & 226.3 & 7.3 & $-97 \%$ & 1.0 & 6.2 & $517 \%$ \\
\hline $\begin{array}{l}90 \text { - optical, photographic, cinematographic, measur- } \\
\text { ing, checking, precision, medical or surgical instru- } \\
\text { ments and apparatus; parts and accessories thereof }\end{array}$ & 1195.5 & 1976.0 & $65 \%$ & 29.2 & 10.0 & $-66 \%$ \\
\hline SUMMARY & 6642.23 & 15023.8 & $126 \%$ & 494.96 & 1262.60 & $155 \%$ \\
\hline
\end{tabular}

Source: own elaboration based on: United Nations Comtrade (2021).

In terms of trade, tariff and non-tariff barriers are also very important. Considering the tightening cooperation between countries, they should be mutually reduced. Changes in the average level of tariffs on goods imported into the country are presented in Figure 4. China has pursued a trade-friendly tariff policy since the early 2000s. In 2000, the average tariff rate was $14.67 \%$, with the largest reduction occurring by 2004 . In Figure 4, it can be seen that the Chinese tariff rate has been systematically reduced from $4.65 \%$ to the $3,39 \%$. In the case of Poland, where the level of rates has been low since the beginning of the analysed period, the value oscillated between $2.00 \%$ and $1.31 \%$ throughout the period and at the end of the analysed period it amounted to $1.69 \%$. Taking into account the difference in average duty rates between the countries, it should be noted that the rates on import in China are higher than in Poland, which indicates a higher level of market protection and higher costs related to export from Poland to China. 


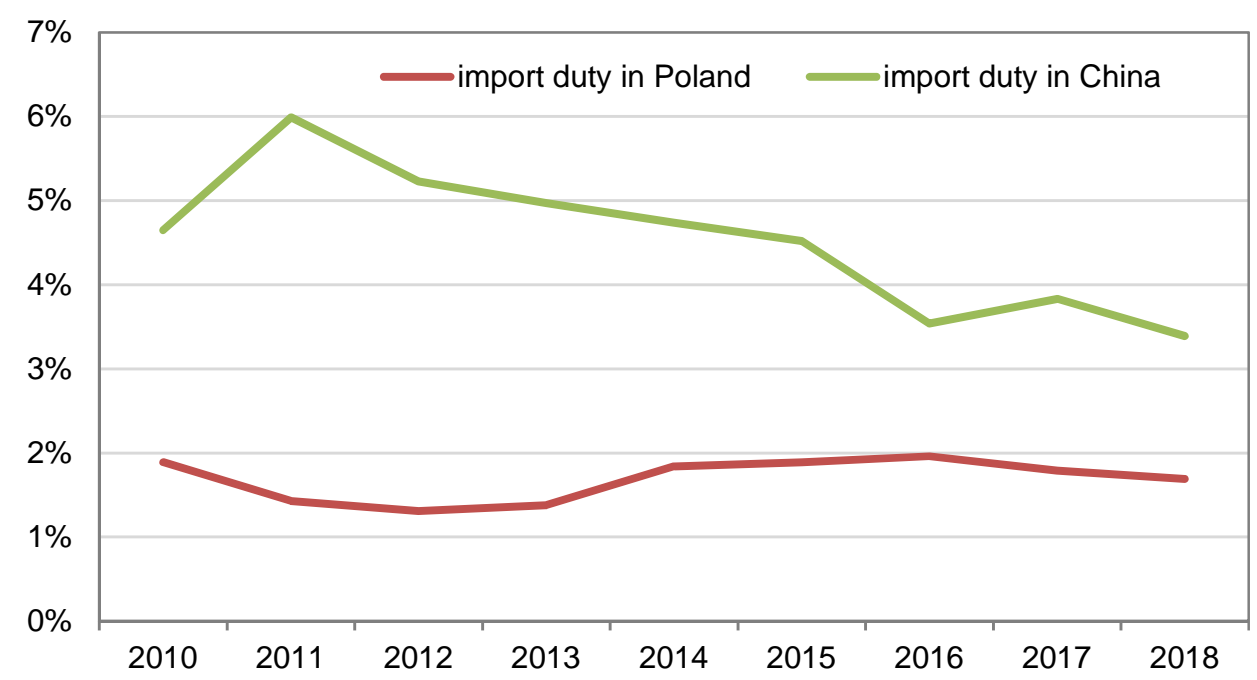

Figure 4. Average percentage rate customs duties on imports of goods by China and Poland in 2010-2018 Source: own elaboration based on The World Bank (2021c).

\section{IDI Research}

Interviews conducted with representatives of the government administration provided information on the current situation in the field of Polish-Chinese trade policy. In their assessment of the changes in relations between the countries, respondents qualified the changes as rather positive, although the relations are not shaped with much enthusiasm and commitment. Their character depends primarily on the time perspective in which it is assessed and the parties. In the short term, an increase in trade intensity may have positive overtones due to possibly extensive cooperation also in terms of technological development. In the long term, however, it is worth noting that China as a strong player on the international market may lead economies to depend on its products and then use the position it has gained.

The assessment of barriers to the trade process has been done in a very broad way. First of all, the attention was directed at the low involvement of entrepreneurs in the process of expansion on the Chinese market. This is due to both the geographical and cultural distance that separates the two countries. Polish entrepreneurs also more often decide on a simple alternative in the form of European markets, which are not so demanding in terms of involvement or knowledge of the rules of international trade. However, in the conducted interviews it was indicated that the companies often give up on the Far East markets without taking into account the benefits they can derive from these markets. Due to the number of consumers on the Chinese market and a growing and capital-rich economy, engagement in the Chinese market can bring benefits comparable to expansion in several European markets. This barrier, however, is assessed as surmountable, due to the great support of institutions such as the Polish Agency for Enterprise Development (PARP) or the Polish Investment and Trade Agency (PAIH), which more and more often include export development programmes on the Chinese market in their activities. The lack of recognition of Polish brands was also mentioned as a barrier. This concerns both rapidly developing start-ups and traditional companies, e.g. from the food industry. This barrier is more difficult to overcome due to the need to commit large capital to compete with Chinese market players in terms of promotion. However, Polish companies often do not have sufficient capital or are not willing to spend it in the form of uncertain investments. The barriers mentioned above are of a permanent nature and have persisted for several years.

In assessing aspects of trade cooperation, both respondents indicated that positive aspects predominate. Such issues as the possibility to diversify Polish exports, building a position in the international supply chain or the development of knowledge in the field of high-tech technologies were equally presented. The most important aspect is participation in the group of global leaders who create cooperation 
between countries at the international level. This aspect is particularly important in view of rapidly advancing globalisation, which marginalises countries not involved in trade and politics. Table 3 presents the results of the survey, which show the barriers and challenges to building further trade relations.

Table 3. List of barriers and challenges to trade identified during the in-depth interview research

\begin{tabular}{|l|l|}
\hline \multicolumn{1}{|c|}{ Barriers } & \multicolumn{1}{c|}{ Challenges } \\
\hline Large cultural differences between markets & $\begin{array}{l}\text { Long-term dependence of Polish economy on trade } \\
\text { with China }\end{array}$ \\
\hline $\begin{array}{l}\text { Need for large financial commitment in the } \\
\text { process of building business cooperation }\end{array}$ & $\begin{array}{l}\text { Low attractiveness of Chinese market for Polish en- } \\
\text { trepreneurs in relation to European markets }\end{array}$ \\
\hline & Dependence of Polish policy on European Union \\
\hline & Uncertainty of relations between China, USA and EU \\
\hline
\end{tabular}

Source: own elaboration based on the interviews.

\section{CONCLUSIONS}

The aim of the study was to review the current situation in the field of Polish-Chinese cooperation and to determine the prospects for this development together with its profitability in terms of achievable benefits. The study was carried out based on desk-research analysis of the found data and conducted in-depth interviews with the representatives of the government administration. Based on data on trade between countries over the last ten years, it should be indicated that trade between countries is intensifying. This is indicated both by the nominal value of exports and by the changes in trade arrangements. In addition to the figures, the upward trend is also supported by expert opinion, which points to a wide range of possibilities for closer cooperation in areas other than just trade. In terms of prospects, it should be shown that due to the COVID-19 pandemic, trends have been altered, but since the beginning of the epidemic many of the indicators have returned to their former levels and trend. In this regard, it should be noted that the directions of Polish-Chinese cooperation are directed towards further development of relations and exchanges. The possible directions of development, however, depend on political actions, which have not been characterized by great involvement so far, and on the business world, which is the basis for creating trade cooperation.

The research makes it possible to determine the degree of development of trade cooperation in high-tech goods at a level that differs from other countries, such as Europe. This proves that the potential of the Chinese market is still untapped. This is largely due to barriers, which should be defined as the lack of sufficient involvement of entrepreneurs in activities related to expansion, which results from the distant location and cultural differences of the market. Another important barrier is also the lack of brand recognition, understood both as individual product brands and brands understood as general good opinions about industries such as e.g. gaming or groceries. In terms of the greatest potential for growth, we can distinguish industries related to new technologies, which are part of the programmes implemented by the Chinese government such as China Standards 2035 or Made in China 2025. These industries include Automotive, especially focusing on the production of electric cars; IT and ICT, all industries related to renewable energy. The above results are in line with the literature, which on the development of cooperation concerning high-tech goods is assessed as perspective.

Conclusions of the study indicate that there is a large and untapped potential for Polish-Chinese cooperation. Its development, which requires involvement from both the political and business sides, may have a positive impact on economic and social development.

In order to examine the aspect of Polish-Chinese cooperation in more detail, the following areas of research have been determined:

- Narrowing the object of research to political cooperation in terms of trade - due to the large role of political determinants, this aspect will enable a thorough analysis of the development directions in this respect. 
- Narrowing the focus of the research to cooperation of business entities - taking into consideration diverse factors influencing international expansion, it is necessary to analyze which factors constitute the greatest barriers for entrepreneurs to carry out cooperation with the Chinese market.

\section{REFERENCES}

Amal, M. (2021). EU-China Comprehensive Agreement on Investment (CAI): Looking through the European Union's perspective. Airlangga: Airlangga University.

GUS (2021). Obroty handlu zagranicznego według krajów $i$ kontynentów. Retrieved from http://swaid.stat.gov.pl/HandelZagraniczny_dashboards/Raporty_predefiniowane/RAP_SWAID_HZ_3_10.aspx on 4 June 2021.

Białowas, T. (2006). Rozwój handlu międzynarodowego po Il wojnie światowej. Toruń: Wyd. A. Marszałek.

Borkakoti, J. (1998). The Linder Hypothesis. In International Trade: Causes and Consequences. London: Springer International Publishing. https://doi.org/10.1007/978-1-349-27014-9_24

Bossche, P. (2005). The Law and Policy of the World Trade Organization. Cambridge: Cambridge University Press.

Brona, A. (2018). One Belt, One Road: new framework for international relations?. Polish Journal of Political Science, 4(2), 58-59.

Gacek, Ł. (2018). Nowe źródła wzrostu gospodarczego Chin: wiedza i innowacje. Humanities Yearbooks, 66 (9), 11.

Hołdak, K., \& Konarzewska, A. (2007). Relations of the European Union with China. National Security Office.

Jaklič, A. \& Svetličič, M. (2019). China and Central and Eastern European Countries within '16+1': Group or Bilateral Relations?. Entrepreneurial Business and Economics Review, 7(2), 83-100. https://doi.org/10.15678/EBER.2019.070205

Kundera, J. (2018). Współczesne teorie wymiany międzynarodowej. Światowy handel po kryzysie 2008 r. In J. Kundera (Ed.), Gospodarka światowa po kryzysie 2008 r. Wrocław: Wydawnictwo Uniwersytetu Wrocławskiego.

Lach, Z. (2014). Polska polityka w wymiarze subregionalnym. Przeglqd Geopolityczny, 7, 17-19.

Łoś-Nowak, T. (2009). Organizacje w stosunkach międzynarodowych. Istota - mechanizmy działania - zasięg. Wrocław: Wydawnictwo Uniwersytety Wrocławskiego.

Nacewska-Twardowska, A. (2020). Factories Europe, Asia, and North America as the main production centers in the 21st century. International Entrepreneurship Review, 6(1), 63-76. https://doi.org/10.15678/IER.2020.0601.04

Olesiuk, A., \& Vashchenko, M. (2001). Międzynarodowe stosunki ekonomiczne - gospodarcze wyzwania XXI wieku. Warszawa: Key Text.

Panda, R., Sethi, M., \& Chaudhuri, S. (2016). Changing Paradigm in Trade Theories: A Review and Future Research Agenda. Indian Journal of Science and Technology, 9(46), 1-6. https://doi.org/10.17485/ijst/2016/v9i46/107291

Portugal-Perez A., \& Reyes J. D., \& Wilson J. S. (2009). Beyond the Information Technology Agreement Harmonization of Standards and Trade in Electronics. Policy Research Working Paper, 2.

Posner, M. (1961). International Trade and Technical Change. Oxford Economic Papers 13(3), 323-341. https://doi.org/10.1093/oxfordjournals.oep.a040877

Rasiah, R. (2002). TRIPs and Capability Building in Developing Economies.Tokyo: The United Nations University.

Stec, G. (2013). „Tradycyjna przyjaźń polsko-chińska” czy „niezłe perspektywy”? Stosunki polsko-chińskie od 1989 roku. Poliarchia, 1, 76-78.

Świerkocki, J. (2004a). Zarys ekonomii międzynarodowej. Warszawa: PWE.

Świerkocki, J. (2004b). Zarys międzynarodowych stosunków gospodarczych. Radom: Polwen.

Szczudlik-Tatar, J. (2015). Polsko-chińskie „strategiczne partnerstwo”: w oczekiwaniu na wymierne rezultaty. The Polish Institute of International Affair, 101(1338), 1.

United Nations Comtrade (2021). Trade Data. Retrieved from https://comtrade.un.org/Data/ on 4 June 2021.

VerWey, J. (2019). Chinese Semiconductor Industrial Policy: Past and Present. Journal of International Commerce and Economics, 7, 13.

Wach, K. (2018). Theoretical foundations for international entrepreneurship. In K. Wach (Ed.), Internationalization of firms in the perspective of international entrepreneurship. Warszawa: PWN, 63-95. 
Wnedt, J. (1997). Geopolityczne uwarunkowania rozwoju i zmian w przebiegu korytarzy tranzytowych w Europie Środkowej. Przeglad Geopolityczny, 28, 31-48.

World Bank (2021a). China. Retrieved from https://data.worldbank.org/country/china on 4 June 2021.

World Bank (2021b). Poland. Retrieved from https://data.worldbank.org/country/poland on 4 June 2021.

World Bank (2021c). Tax. Retrieved from https://data.worldbank.org/indicator/TM.TAX.MRCH.\%20WM.AR.ZS? locations=CN-PL on 4 June 2021.

World Integrated Trade Solution. (2021). Top Exporters and Importers by country and region. Retrieved from https://wits.worldbank.org/CountryProfile/en/Country/WLD/Year/2018/TradeFlow/EXPIMP on 4 June 2021.

WTO (2007). 2007 World Trade Report: Six Decades of Multilateral Cooperation, What Have we Learnt?. Geneva: WTO Publications, 207-220.

\section{Author}

\section{Celestyna Miłoś}

Master of International Economics (2021, Cracow University of Economics, Poland). Her research interests include corporate internationalisation strategies, international business management and international marketing. Correspondence to: Mgr Celestyna Miłoś, Cracow University of Economics, ul. Rakowicka 27, 31-510 Krakow, Poland, e-mail: celestynajuliamilos@gmail.pl or s200665@student.uek.krakow.pl ORCID $\odot$ http://orcid.org/0000-0001-7596-1541

\section{Acknowledgements and Financial Disclosure}

The author would like to thank two anonymous reviewers and dr Marta Ulbrych for their comments and suggestions, which help to improve the final version of this article.

\section{Conflict of Interest}

The author declares that the research was conducted in the absence of any commercial or financial relationships that could be construed as a potential conflict of interest.

\section{Copyright and License}

This article is published under the terms of the Creative Commons

Attribution - NoDerivs (CC BY-ND 4.0) License

http://creativecommons.org/licenses/by-nd/4.0/ 